\title{
Phytochemical investigation of extracts of rhizomes of Hedychium Spicatum Sm. in A. Rees of Himachal Pradesh, India
}

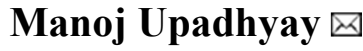 \\ Department of Chemistry, Monad University Hapur- (U.P.), India \\ Sourobhi Barman \\ Department of Chemistry, Monad University Hapur- (U.P.), India \\ Senthil Kumar \\ Department of Chemistry, Monad University Hapur- (U.P.), India \\ Vikas Tyagi \\ RSS Degree College, Hapur- (U.P.), India
}

\begin{tabular}{|c|c|}
\hline ARTICLE INFO & BSTRACT \\
\hline $\begin{array}{l}\text { Available online: } 19 \text { December } 2021 \\
\text { Key Words: } \\
\text { Hedychium Spicatum } \\
\text { Phytochemical screening } \\
\text { Dextro rotatory } \\
\text { Specific gravities } \\
\text { Proteins } \\
\text { Alkaloids } \\
\text { Carotenoids }\end{array}$ & $\begin{array}{l}\text { Hedychium Spicatum is a rhizomatous perennial plant of various } \\
\text { ethnomedicinal significance, which belongs to Zingiberaceae family.In the } \\
\text { present study, H.Spicatum extracts were investigated for the presence of major } \\
\text { phytochemical compounds. The dried and powdered rhizomes were extracted } \\
\text { employing Soxhlet extraction with selective solvents of varying polarities viz } \\
\text { water, ethanol, petroleum ether and diethyl ether. Qualitative phytochemical } \\
\text { analysis of each of these extracts of H.Spicatum suggested the existence of } \\
\text { flavonoids, phenolic compounds, carotenoids, alkaloids, reducing sugars } \\
\text { (carbohydrate), proteins, steroids, saponins and oils. Greater extent of } \\
\text { unsaturation was observed in diethyl ether and petroleum ether extracts. These } \\
\text { extracts were also examined for their physico-chemical properties. All of the } \\
\text { studied extracts were found to be optically active, specifically dextro rotatory. } \\
\text { The phytochemicals present in the rhizomes suggest potential ethnomedicinal } \\
\text { application of the species in the treatment, control and management of diseases } \\
\text { and for new drug discovery. }\end{array}$ \\
\hline
\end{tabular}

\section{Introduction}

The twenty first century has seen an unprecedented interest in traditional medicine accompanied by an enormous rise in the demand for drugs from plant sources. Herbal medicines have become increasingly quintessential part of the international pharmacopeia. Numerous studies were put forward in correlating phytochemical constituents of a plant with its pharmacological activity (Cseke et al., 2016; Gupta,1994; Vaidya et al.,1994) research groups world over have correlated the botanical properties of plants with their pharmacological activity (Rawat et al.,1997). An exhaustive multipronged research aimed at correlating botanical and phytochemical properties to specific pharmacological activities are expected in future (Bagetta et al., 2016; Dahanukar et al., 2000). Further studies can be carried out regarding extraction, isolation and identification of active principles and pharmacological studies of isolated compound based on these preliminary findings. Therefore, these scientific studies may be exploited to develop future drugs. While developing potent drugs from natural products various aspects need to be addressed, including the determination and selection of primary screening assays that are pivotal to ensure a selection of extract or molecule with appropriate pharmacological action worth pursuing. The plant material must primarily be exposed to an appropriate extraction process to assess the plant constituents for their biological activity. The term 'extraction' is a technique employed to separate and isolate target molecules using selective solvents through standard processes. An extensive range of technologies are available for the purpose. The crude extract is evaluated for its potential biological activity. The sequentially

Corresponding author E-mail: upadhya.mansha200@gmail.com

Doi: https://doi.org/10.36953/ECJ.2021.22336

This work is licensed under Attribution-Non Commercial 4.0 International (CC BY-NC 4.0)

(C) ASEA 
fractioned crude extracts are subjected to further suitable bio-assay tests, in order to evaluate them for potential biological activity (Bobzin et al., 2000; Gaudêncio et al., 2015).

Hedychium. spicatum is a conventional herbal medicine, used as remedy of cough, wounds, ulcer (Badola ,2009; Dwivedi et al.,2019; Giri et al.,2010), fever (Sahu ,1979; Savitharamma et al., 2007; Tavares et al., 2020) breathing problems(Kumari et al.,2011; Badoni et al., 2010) and hiccough (Rawat et al.,2021; Sahu.,1979; Savitharamma et al., 2007). The plant Hedychium spicatum $\mathrm{sm}$. in a.rees is a perennial rhizomatous herb (syn. Gandasulium spicatum (Sm.) Kuntze, Hedychium acuminatum Roscoe) belongs to zingiberaceae family. It is a native plant related to the genera Hedychium. It spreads all through the subtropical Himalaya at an altitudinal range of 1000-3000 m (Samant et al., 1997; Thakur et al., 1989). The rhizomes are usually recognised as Kapurkachari in local language or Ban Haldi (Samant et al., 1997) in Hindi and Shati in Bangla and traditional name is Gandhamulika (Sahu, 1979; Chunekar ,1960). Hedychium. spicatum grows up to at least one metre height with elongated stem. The rhizomes have a pungent odor and a bitter flavor. It closely resembles Hedychium coronarium. The white ascending flowers are borne in terminal spikes and the leaves are approximately $30 \mathrm{~cm}$ long glabrous beneath, earning it the name spiked ginger lily. The leaves vary in breadth, glabrous, oblong and lanceolate. Fruit is capsule type; glabrous and globose (Nadkarni, 1976; Kirtikar et al., 1935). Rhizomes are externally yellowish-brown, which darken on storage. These are 15-20 cm long; 2.0 $2.5 \mathrm{~cm}$ in diameter; with a rough reddish brown layer marked with numerous scars and circular rings; rudiments of rootlets are visible (Handa, 1997).

\section{Material and Methods}

The authentic rhizomes were collected from CSIRInstitute of Himalayan Bioresource Technology, Palampur, Himachal Pradesh. The rhizomes were washed and then rinsed with distilled water. The rhizomes were chopped into pieces, shade dried and finally dried for 2-3 days at ambient temperature and then pulverized to obtain a coarse powder.

\section{Preparation of rhizome extracts}

(A) Aqueous extract: $500 \mathrm{ml}$ double distilled water were added to 100 grams of the powdered rhizome and boiled for $1 \mathrm{~h}$ at $100^{\circ} \mathrm{C}$. The extract was subjected to filteration and vacuum evaporation. A dark brown solid (15.4 g) was obtained from Hedychium spicatum .

(B) Ethanolic extract: In a Soxhlet extractor $100 \mathrm{~g}$ crushed material was placed and $500 \mathrm{ml}$ of ethanol were added to it. The material was extracted for 72 hrs at $78^{\circ} \mathrm{C}$. Dark brown mixture was obtained. 500 $\mathrm{ml}$ of ethanol were added again to the soxhlet and kept for another $72 \mathrm{hrs}$. The process was repeated till the extract became colourless. All the extracts were pooled and vacuum distilled. A dark brown solid (5.25 g) was obtained.

(C) Diethyl ether extract: In a Soxhlet extractor $100 \mathrm{~g}$ of the powdered rhizome was placed and 500 $\mathrm{ml}$ of diethyl ether were added. The material was extracted at $34^{\circ} \mathrm{C}$ for $72 \mathrm{hrs}$. The extract subjected to filtration and vacuum evaporation to yield yellowish brown viscous oil (3.56 g).

(D) Petroleum ether extract: In a Soxhlet extractor $100 \mathrm{~g}$ of the powdered rhizome was placed and $500 \mathrm{ml}$ of petroleum ether were added. The extraction was carried out at $60-80^{\circ} \mathrm{C}$ for 72 hrs. The extract subjected to filtration and vacuum evaporation to yield yellowish light brown viscous oil $(1.68 \mathrm{~g})$.

\section{Phytochemical Screening}

Investigations for the presence of different class of natural product compounds, specific gravities, optical rotation, refractive index and $\mathrm{pH}$ were carried out by usual methods. The saponification values, acid values and iodine values were also determined for the essential oils and for the various extracted materials employing the established methods (Garratt, 1964; Guenther, 1963; Tyagi et al., 2013) and in monographs of I.S.I. (1984).

\section{Results and Discussion}

Soxhlet extraction was employed and the yield has been found to be varying depending upon the polarity of the solvent used and the solublities of the components present. The findings indicate that better extraction yields are obtained by using polar solvents (Iloki-Assanga et al., 2015; Lapornik et al., 2005; Nawaz, Nawaz et al., 2020). The colours of the decoctions, too, were observed to be varying. Table 1 summarizes the yields and physico- 
chemical properties of extracted materials, while the results of the phytochemical tests are described in Table 2. The extraction of the rhizomes through water provided a dark brown solid material with sharp odour and the yield was found to be maximum among all the solvents employed in the present work (Table 1). Presence of high percentage of water soluble substances in the rhizomes is suggested by highest yield in the case of the crude aqueous extract (Sravani et al., 2012; Tchabo et al., 2018). The existence of, reducing sugar (carbohydrate), protein, certain carboxylic acids, steroids and saponin as major phytochemical groups was indicated by the phytochemical screening of the aqueous extract of $H$. spicatum (Table 2). Low acid values and the $\mathrm{pH}$ values of higher than 5.0 indicate that not much free acids are present. The presence of comparatively high molecular weight compounds and much less unsaturated compounds is suggested by relatively low saponification and iodine values of the aqueous extract. Extraction through ethanol gives dark brown solid with pungent odour. Most of the part of ethanol extract was insoluble in water but soluble in mixture of ethanol and water (80:20). The ethanol extract comprises of aldehydic and ketonic compounds, carbohydrates, steroids and the flavonoids but devoid of alkaloids. The yield obtained in ethanol extract was found to be lesser with respect to the yield obtained in the case of aqueous extract. The relatively high saponification value and lower iodine value of ethanolic extract is indicative of presence of relatively low molecular weight compounds with lesser degree of unsaturation.

Table 1: Physicochemical analysis of the extracts of $\boldsymbol{H}$. spicatum

\begin{tabular}{|c|c|c|c|c|}
\hline \multirow[b]{2}{*}{ Properties } & \multicolumn{4}{|l|}{ Extract of $H$. spicatum } \\
\hline & Pet. Ether & Diethyl ether & Ethanol & Aqueous \\
\hline Colour of Decoction & Yellow & Yellowish brown & Dark brown & Dark red \\
\hline Colour of Extract & Yellowish light brown & Yellowish brown & Dark brown & Dark brown \\
\hline State & Viscous oil & Viscous oil & Solid & Solid \\
\hline Odour & Spicy & Sweet & Sweet & Sharp \\
\hline Yield $(\%, w / w)$ & 3.67 & 4.86 & 6.21 & 17.41 \\
\hline pH & 4.61 & 5.65 & 3.99 & 6.70 \\
\hline $\begin{array}{l}\text { Refractive index } \\
\text { (0.025\% solution) }\end{array}$ & 1.31 & 1.34 & 1.37 & 1.37 \\
\hline Specific gravity $\left(30^{\circ} / 30^{\circ}\right)$ & 0.8662 & 0.8937 & 0.8646 & -- \\
\hline $\begin{array}{l}\text { Optical rotation }\left(25^{\circ} \mathrm{C}\right) \\
(0.025 \% \text { solution })\end{array}$ & $3^{\circ} 20^{\prime}$ & $2^{\circ} 06^{\prime}$ & $4^{\circ} 01^{\prime}$ & $4^{\circ} 07^{\prime}$ \\
\hline Acid value & 37.86 & 35.38 & 33.35 & 16.28 \\
\hline Saponification value & 151.6 & 142.2 & 154.2 & 73.00 \\
\hline Iodine value & 73.87 & 41.76 & 13.65 & 14.54 \\
\hline
\end{tabular}


Table 2: Phytochemical Analysis of the extracts of $\boldsymbol{H}$. spicatum

\begin{tabular}{|c|c|c|c|c|}
\hline \multirow[b]{2}{*}{ Chemical tests } & \multicolumn{4}{|c|}{ Extract of $H$. spicatum } \\
\hline & Pet. Ether & Diethyl ether & Ethanol & Aqueous \\
\hline \multicolumn{5}{|c|}{ Proteins and amino acids } \\
\hline Xanthoproteic test & - & + & - & - \\
\hline Biuret test & - & - & - & + \\
\hline \multicolumn{5}{|l|}{ Alkaloids } \\
\hline Mayer's test & + & - & - & - \\
\hline \multicolumn{5}{|l|}{ Carbohydrates } \\
\hline Molisch test & - & - & + & + \\
\hline \multicolumn{5}{|l|}{ Carotenoids } \\
\hline Sulphuric acid test & - & - & - & - \\
\hline \multicolumn{5}{|l|}{ Flavonoids } \\
\hline Alkaline reagent test & + & + & + & - \\
\hline Lead acetate test & + & + & + & - \\
\hline \multicolumn{5}{|l|}{ Steroids } \\
\hline Salkowski's test & - & + & + & + \\
\hline \multicolumn{5}{|l|}{ Aldehydic } \\
\hline Tollen's test & + & - & + & + \\
\hline Fehling solution & + & - & + & + \\
\hline Schiff's reagent & + & - & + & - \\
\hline Ketonic & - & - & + & - \\
\hline Carboxylic & - & - & - & + \\
\hline Phenolic & + & - & - & - \\
\hline \multicolumn{5}{|l|}{ Unsaturation } \\
\hline Bromine water test & + & + & + & + \\
\hline Alkaline $\mathrm{KMnO}_{4}$ test & + & + & + & + \\
\hline
\end{tabular}

Key:(-) =Absent, $(+)=$ Present

Yield in diethyl ether is marginally lower than that in alcohol. Instead of solid material, it gave yellowish brown viscous oil. The obtained oil was almost neutral in character $(\mathrm{pH} 4.54)$ and lighter than water (Tables 1). It was found to be dextro rotatory with enough acid value (Tables 1 ) and high degree of unsaturation as indicated by its iodine value (Table 1). However, a relatively large saponification value suggests the existence of greater amount of low molecular weight compounds. The carbohydrates and were not found in the extracted mass but indicated presence of flavonoids, steroids and proteins. Because of the sweet, characteristic odor and its solubility in ether, the extracted oil can be used in perfumery.

Extraction through the non-polar solvent petroleum ether yielded reddish brown viscous oil. The yield of the substance obtained through petroleum ether extraction is the lowest of all the solvents, indicating lesser amount of fatty acids. Flavonoids and carbohydrates were absent but some aldehydes and phenolic compounds were found, as evident by their positive tests in petroleum ether extract (Table 2). Petroleum ether extract of a plant material usually contains the fatty oils (Tse, 2005). A good saponification value (Table 1) indicated the presence of sufficient amount of saponifiable matter. A slight acidic $\mathrm{pH}$ of the extracted samples confirms their suitability in preparation of syrups, skin ointments and also as colorant for food and drug. All the extracts were dextro rotatory thus enhancing the probability of exhibiting biological activity as molecular chirality directs whole-cell chirality (Inaki, 2016; Morozov, 1979). Since phenolic compounds are present, it's possible that such extracts may show antioxidant effects. These extracts could be utilized to isolate and identify antioxidant molecules that could be studied further in the treatment of diseases caused by free radicals.

\section{Conclusion}

The study of $H$. spicatum extracts showed the presence of almost similar groups of compounds. 
Carbohydrates, protein, steroids, and saponin are important phytochemical groups found in the aqueous extract of $H$. spicatum. These compounds in the form of water soluble extracts seem to be quite important as they find use in various herbal formulations and ethnomedicinal applications. Aldehydic and ketonic groups, carbohydrates, steroids, and flavonoids are found in the ethanol extract. The alcohol soluble compounds particularly flavonoids can act as antioxidants. The ether extracted oily mass rich in flavonoids and steroids with characteristic sweet odour can also be used in perfumery apart from pharmaceutical applications.

\section{References}

Badola, H. K. (2009). Hedychium spicatum-A commercial Himalayan herb needs entrepreneurship at local level. NonWood News, 19, 26-27.

Badoni, A., Bisht, C., \& Chauhan, J. S. (2010). Micropropagation of Hedychium spicatum Smith using in vitro shoot tip. Stem Cell, 1(1), 11-13.

Bagetta, G., Cosentino, M., Corasaniti, M. T., \& Sakurada, S. (Eds.). (2016). Herbal medicines: development and validation of plant-derived medicines for human health. CRC Press.

Bobzin, S. C., Yang, S., \& Kasten, T. P. (2000). LC-NMR: a new tool to expedite the dereplication and identification of natural products. Journal of Industrial Microbiology and Biotechnology, 25(6), 342-345.

Chunekar K.C.(1960).Bhav Prakasa Nighantu (Hindi translation).Bharati Publications, Varanasi.

Cseke, L. J., Kirakosyan, A., Kaufman, P. B., Warber, S., Duke, J. A., \& Brielmann, H. L. (2016). Natural products from plants. CRC press.

Dahanukar, S. A., Kulkarni, R. A., \& Rege, N. N. (2000). Pharmacology of medicinal plants and natural products. Indian journal of pharmacology, 32(4), S81S118.

Dwivedi, T., Kanta, C., Singh, L. R., \& Prakash, I. (2019). A list of some important medicinal plants with their medicinal uses from Himalayan State Uttarakhand, India. Journal of Medicinal Plants, 7(2), 106-116.

Garratt D.C. (1964).The Quantitative Analysis of Drugs, (Vol.III), Chapman Hall International, London:

Gaudêncio, S. P., \& Pereira, F. (2015). Dereplication: racing to speed up the natural products discovery process. Natural product reports, 32(6), 779-810.
The current investigation also discovered that the Pet. ether extract of H. spicatum has a considerable amount of phenolic compounds that may have antioxidant properties. As a result, this plant could be utilized to isolate and identify antioxidant chemicals that could be studied further in the treatment of diseases caused by free radicals.

\section{Acknowledgement}

The authors owe a debt of gratitude to CSIR-IHBT Palampur, Himachal Pradesh and Department of Chemistry, Monad University, Hapur.

Giri, D., Tamta, S., \& Aseesh, P. (2010). A review account on medicinal value of Hedychium spicatum Buch-Ham ex Sm: Vulnerable medicinal plant. Journal of Medicinal Plants Research, 4(25), 2773-2777.

Guenther E. (1963), The Essential Oils. D.Van Nostrand Company. New York.

Gupta, S. S. (1994). Prospects and perspectives of natural plant products in medicine. Indian J Pharmacol, 26(1), 1-12.

Handa, H. S., \& Kaul, M. K. (1997). Supplement to cultivation and Utilization of Aromatic Plants.

Kirtikar K.R., Basu R.D. (1935). Indian Medicinal Plants (2 ${ }^{\text {nd }}$ Edition). International Book Distributors, Dehradun.

Kumari, P., Joshi, G. C., \& Tewari, L. M. (2011). Diversity and status of ethno-medicinal plants of Almora district in Uttarakhand, India. International journal of biodiversity and conservation, 3(7), 298-326.

Lapornik, B., Prošek, M., \& Wondra, A. G. (2005). Comparison of extracts prepared from plant by-products using different solvents and extraction time. Journal of food engineering, 71(2), 214-222.

Morozov, L. (1979). Mirror symmetry breaking in biochemical evolution. Origins of life, 9(3), 187-217.

Nadkarni, K., \& Nadkarni, A. K. (1976). Indian Materia Medica, Popular Prakashan Pvt. Ltd., Bombay, 1, 799.

Nawaz, H., Shad, M. A., Rehman, N., Andaleeb, H., \& Ullah, N. (2020). Effect of solvent polarity on extraction yield and antioxidant properties of phytochemicals from bean (Phaseolus vulgaris) seeds. Brazilian Journal of Pharmaceutical Sciences, 56.

Rawat, A. K. S., Mehrotra, S., Tripathi, S. C., \& Shome, U. (1997). Hepatoprotective activity of Boerhaavia diffusa L. roots - a popular Indian ethnomedicine. Journal of ethnopharmacology, 56(1), 61-66. 
Rawat, A., Prakash, O., Kumar, R., Arya, S., \& Srivastava, R. M. (2021). Hedychium spicatum Sm.: Chemical Composition with Biological Activities of Methanolic and Ethylacetate Oleoresins from Rhizomes. Journal of Biologically Active Products from Nature, 11(3), 269-288.

Sahu, R. B. (1979). Clinical trial of Hedychium spicatum in tropical pulmonary eosinophilia. J Nepal Pharm Assoc, 7, $65-72$.

Samant, S. S., \& Dhar, U. (1997). Diversity, endemism and economic potential of wild edible plants of Indian Himalaya. The International Journal of Sustainable Development \& World Ecology, 4(3), 179-191.

Savithramma, N., Sulochana, C., \& Rao, K. N. (2007). Ethnobotanical survey of plants used to treat asthma in Andhra Pradesh, India. Journal of Ethnopharmacology, 113(1), 54-61.

Sravani, T., Paarakh, P. M., \& Vedamurthy, A. B. (2012). Isolation of phytoconstituents from the rhizomes of Hedychium spicatum Buch. Ham. Journal of Pharmacy Research, 5(1), 526-527.
Tavares, W. R., Barreto, M. D. C., \& Seca, A. M. (2020). Uncharted source of medicinal products: The case of the Hedychium genus. Medicines, 7(5), 23.

Tchabo, W., Ma, Y., Kwaw, E., Xiao, L., Wu, M., \& T. Apaliya, M. (2018). Impact of extraction parameters and their optimization on the nutraceuticals and antioxidant properties of aqueous extract mulberry leaf. International Journal of Food Properties, 21(1), 717-732.

Tse, S. Y. (2005). Food and nutritional analysis| Coffee, Cocoa, and Tea.

Tyagi, D. K., \& Kumar, N. (2013). Physico-chemical investigation of variously extracted medicinally useful materials from the rhizomes of Alpinia calcarata Rosc. of Kumaun Region, India. Environment Conservation Journal, 14(1\&2), 127-129.

Vaidya, A. B., \& Antarkar, V. D. (1994). New drugs from medicinal plants: opportunities and approaches. The Journal of the Association of Physicians of India, 42(3), 221-2. 